\title{
Pedagogical Competencies and Classroom Anxieties in Teaching General Music
}

\section{RAYVIN D. PESTAÑO ${ }^{1}$ AND FLORANTE P. IBARRA ${ }^{2}$}

\begin{abstract}
This study utilized a descriptive correlational research design to examine the pedagogical competencies and classroom anxieties in teaching general music of 50 public junior high school MAPEH (Music, Arts, Physical Education \& Health) teachers in Gapan City, Philippines. Quantitative data were gathered using questionnaire as the main instrument involving statements measured through Likert scale. With a six-month data gathering, Pearson $r$ was utilized in the analysis. Results disclosed that musical skills and knowledge were significantly correlated with pedagogical competencies and classroom anxieties in teaching general music. Recommendations on capacitating MAPEH teacher's musical skills and knowledge must be considered to further improve the quality of music education.
\end{abstract}

\section{Keywords}

Classroom anxieties, general music, pedagogical competencies, musical skills, musical knowledge

1 College of Education, Central Luzon State University, Philippines, e-mail: rayvin.pestano@clsu2.edu.ph

2 Department of Education and Related Studies, College of Education, Central Luzon State University, Philippines, e-mail: fpibarra@,clsu.edu.ph 


\section{IRJE | Indonesian Research Journal in Education | | Vol. 5 | No. 1|June | Year 2021|}

\section{Introduction}

Music, Arts, Physical Education and Health (MAPEH) is a mandatory course from elementary to junior high school which is a combination of different disciplines. Teachers in the junior high school generally encounters challenges and struggles in teaching one of MAPEH's component parts - Music. While Music is considered an academic discipline and must be recognized as such (Atabug, 1996), MAPEH teachers' pedagogical competencies might be affected when one has acquired inadequate musical skills/knowledge to teach a specific musical concept. One of its impacts would lead to some sort of classroom anxiety in teaching general music to students. As stipulated in the Revised Basic Education Curriculum (RBEC, 2002)both in the elementary and secondary levels, the minimum teaching and learning competencies are as follow: singing (alone and with others), reading musical notation, improvising (rhythmic patterns, melodic improvisation or variation), creating music (composing or arranging), listening to music (describing and analyzing), performing (solo instrument or with others) and understanding music in relation to history and culture (Atabug, 1996).

Pedagogical competencies to teaching general music in the classroom require some degree of competency and musical skills which are imperative in the teaching and learning process. In its broadest sense, pedagogical competency is the ability to do or perform something successfully or efficiently. Specifically, it concerns about teaching capacity, from lesson plans to approaches to teaching performance including classroom management. As topics progress from simple to complex, MAPEH teachers' skills (musicianship) is imperative to sustain the quality of instruction. When a teacher feels that his/her acquired music skill is insufficient, there will also a feeling of anxiety in performing the assigned teaching task. Because of the huge components of musical concepts being taught to students, music teachers with less musical knowledge and skills are exposed most likely to some extent of teaching anxiety. Teaching anxiety is a usual human experience applicable to various settings. As defined by Thomas (1976), teaching anxiety can be described as "feelings, beliefs, or behaviors that interfere with a person's ability to start, continue, or finish teaching tasks" (p.28). In this case, teacher preparation, classroom management and public speaking are affected by teaching anxiety. While there are number of studies have been conducted to determine the teacher's pedagogical competencies (Emiliasari, 2018; Mardapi \& Herawan, 2018; Sumual \& Ali, 2017), there are limited researchers in the context of competencies in teaching music (Kovalev et al., 2016; Marcheva, 2018), assessing teachers competence in music (Funmilayo, 2019; Maranzano, 2002), and teachers' teaching anxiety (Sinclair \& Ryan, 1987; Thomas \& Thoresen, 1976). This is where this inquiry hoped to address MAPEH teachers' pedagogical competencies and classroom anxieties in teaching general music to junior high school students. Purposively, it hoped to examine how effective a MAPEH teacher with high level of musical skills and in contrary, it would also define how classroom anxiety affects instruction in general music when MAPEH teachers lack musical skills. This study was conducted to describe the musicianship, pedagogical competencies and classroom anxieties of the respondents. Furthermore, to investigates the impacts of musicianship (musical knowledge and skills) to pedagogy and anxiety in general musical class. 


\section{IRJE | Indonesian Research Journal in Education | | Vol. 5 | No. 1|June | Year 2021|}

\section{Literature Review}

Teacher competency is believed to be an integral part in transmitting certain skills and knowledge to students for the reason that it deals with "teachers' belief and ability to plan and execute courses of action necessary to successfully achieve a specific teaching objectives in a particular context" (Tschannen-moran \& Woolfolk, 2007, p.223). Numerous studies on competencies in teaching have been documented thus far (Devries, 2013; Johnson \& Matthews, 2015 ; Juchniewicz, 2010; Macleod \& Nápoles, 2014), teachers perceptions and behaviors in relation to teacher competencies (Madsen \& Cassidy, 2005; Taebel, 1990), and assessing teacher competencies (Danielsons, 2009; Mohanna et al., 2007; Nielsen, 2014). Teaching anxiety is a usual human experience applicable to various settings. In a study by Plaut (1998), an estimated eight percent of all people experience some degree of anxiety when they become the center of attention. Teaching anxiety in general music classroom has always been a constant issue in teacher education institution. Various studies have been conducted about teaching anxiety in classroom (Gardner \& Leak, 1994), prevalence and severity of teaching anxiety (Ameen et al., 2002), coping strategies and various anxieties (Roach, 2003), personal effects on teaching anxiety and teaching strategies (Houlihan et al., 1969), and teaching anxieties in classroom management (Peker, 2009; Oral, 2012).

This study was based primarily on framework of teaching by Danielson (2009) and Spielberger's (1989) Trait-State theory on Anxiety. Framework for Teaching explores the various areas of competence that a teacher needs to develop and have expertise. It encompasses four domains of teaching responsibility such as planning and preparation, classroom environment, instruction and professional responsibilities. On the other hand, Trait-State theory on Anxiety focuses mainly in emotional state or a condition that is characterized by subjective, consciously perceived feelings of tension and apprehension and perceived threats in the environment. This covered three interrelated areas such as behavioral, psychological and emotional characteristics. By looking through this lens, issues related to pedagogical competencies and classroom anxieties in teaching general music had been given prime emphasis. This study hoped to critically examine how an acquired musical knowledge and skills define teachers' pedagogical competencies and teaching anxieties in teaching general music class. Figure 1 shows the conceptual framework of the study.

In the conceptual framework, the independent variables included the socio-demographic profile such as age, sex, bachelors' degree, highest educational attainment and number of years in service and musicianship which comprised of musical knowledge and musical skills. Pedagogical competencies such as planning and preparation, classroom environment, classroom instruction, professional responsibilities and classroom teaching anxieties which include behavioral, psychological and emotional characteristics served as dependent variable. As shown on the figure, it had established the interrelationships and correlations of the variables. 


\section{IRJE | Indonesian Research Journal in Education | | Vol. 5 | No. 1|June | Year 2021|}

Figure 1. Conceptual framework of the study showing the relationship of the independent and dependent variables

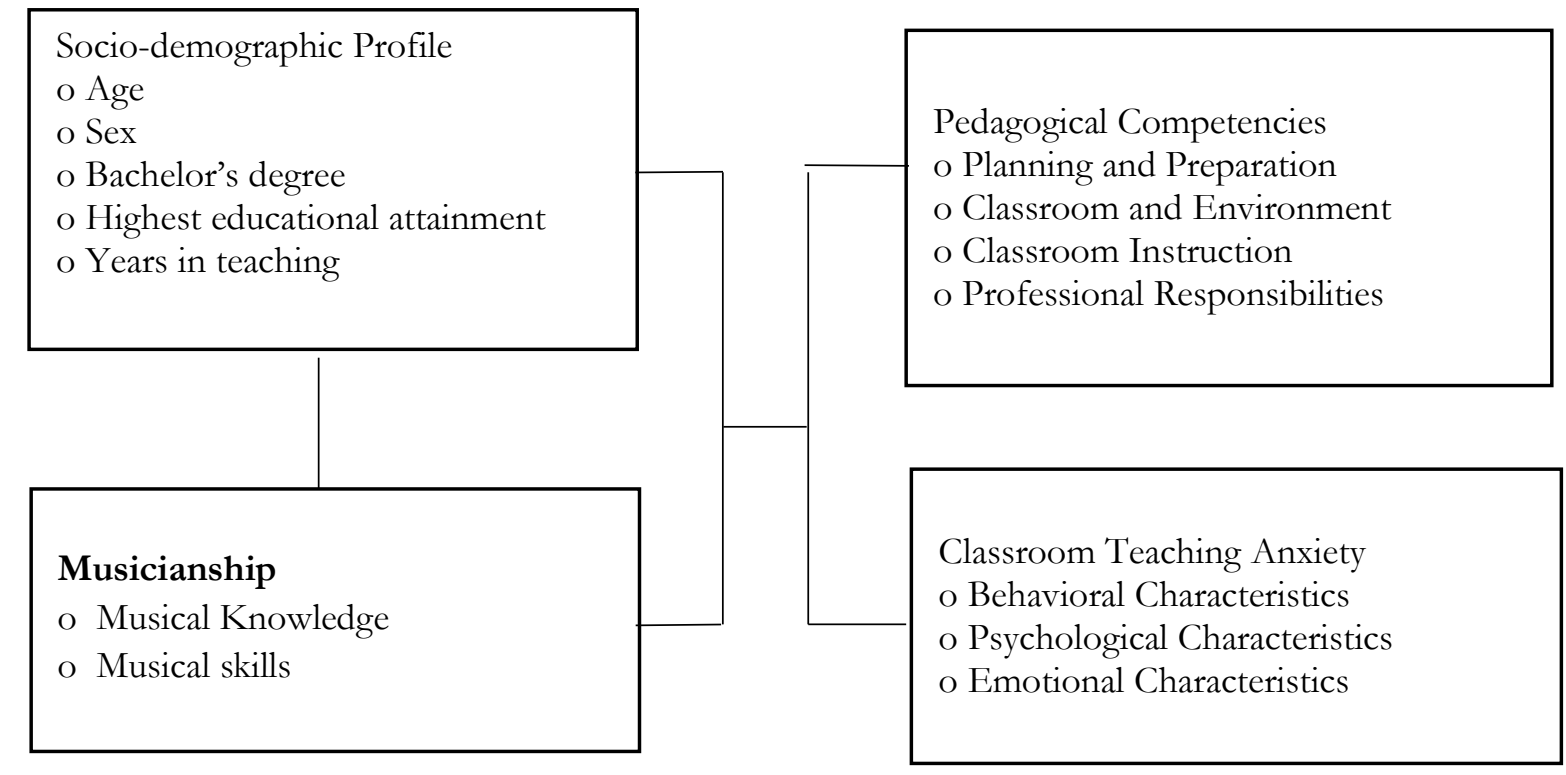

\section{Methodology}

\section{Research design, site, and participants}

Descriptive research design was utilized to investigate the state of musicianship associated with pedagogical competencies and classroom teaching anxieties in teaching general music class among selected junior high school MAPEH teachers in the division of Gapan City. Bernard (2006) describes the research design as a blue print, or outline, for conducting the study in such a way that maximum control will be exercised over factors that could interfere with the validity of research results. In this study, it was used to determine the socio-demographic profile and musicianship (musical knowledge and skills) and their significant links to pedagogical competencies and classroom teaching anxieties.

The population in this study was junior high school teachers teaching the subject MAPEH (Music, Arts, Physical Education and Health). There were a total of $50 \mathrm{MAPEH}$ teachers-respondents from eight (8) public secondary schools in Gapan City, Nueva Ecija Philippines. Total population sampling was used. There were a total of $50 \mathrm{MAPEH}$ teachers who participated in this study. Bernard (2006)defines total population sampling as a sampling technique that involves examining the entire population that have a particular set of characteristics. It is more commonly utilized with relatively small number of cases being investigated, thus, gaining complete representation of respondents in this study. 


\section{IRJE | Indonesian Research Journal in Education | | Vol. 5 | No. 1|June | Year 2021|}

\section{Data collection and analysis}

Survey questionnaires were personally administered by the researcher to the respondents after seeking approval from the Schools Division Superintendent of Gapan City, Nueva Ecija Philippines. Furthermore, the research instrument was guided by Murcia et al. (2015) "Questionnaire in evaluating teacher's competency" and revised according to the needs of the study. To determine the instruments validity and reliability, a pilot test was made and it earned a Cronbach alpha of 0.923 .

Teacher respondents were likewise provided with orientation and explanation of the purpose of the study as well as the instructions in each item in the survey-questionnaires. Data analysis including frequency count, percentage, standard deviation and means were utilized in determining the socio-demographic characteristics and musicianship of the respondents. Pearson correlation was used to examine the relationship between socio-demographic profile, musicianship of the respondents and their pedagogical competencies and classroom teaching anxieties.

\section{Findings and Discussion}

\section{Teachers' socio-demographic profiles}

Table 1 presents the socio-demographic profile of the respondents. Fewer than half or $20(40 \%)$ of teachers were 21-29 years old followed by 12 (24\%) who were 30-39 years old. Nine teachers $(18 \%)$ were $40-49$ years old, seven (14\%) who were 50-59 years old and two (4\%) disclosed that they were 60 years old above. Loughlin and Barling (2001) noted that "young workers" represent the workforce and are mostly found to be very active. In terms of sex, most of the teachers (29 or 58\%) were female while $21(48 \%)$ were male. This implies that female teachers dominated the teaching force of MAPEH in the Division of Gapan city. According to Richardson and Watt (2006) women showed stronger motivation than men in their desire to work with children/adolescent. With regards to bachelors' degree, majority of the teachers (23 or 46\%) were BSEd Other major graduates, followed by 22 $(44 \%)$ BSEd MAPEH and five $(10 \%)$ graduated in other programs. This implies that teachers are being hired because of necessity regardless of specialization of the teacher. Johansson and Myrberg (2019), emphasized the importance of specialist teacher in teaching the subjects effectively. They also found out that teacher's specialization has a positive relationship with student's achievement. As to highest educational attainment, majority of the respondents (32 or 64\%) earned master's units, followed by $13(26 \%)$ who have not yet pursued graduate studies, five (10\%) obtained their masters' degree and none among them have earned units nor finished doctorate degree. In years of teaching, more than half of the teachers belong to the bracket of $1-10$ years (34 or $68 \%$ ) while eight (16\%) belong to the $11-20$ years in teaching. Five (10\%) had 21-30 years in teaching whereas three $(6 \%)$ had 31 years above in teaching. Harris and Sass (2011) noted that teachers with more than five years of experience are more effective than teachers with no experience. Hence, teachers with more years of experience tend to increase effectiveness in teaching. 
Table 1. Socio-demographic profile of the respondents

\begin{tabular}{|c|c|c|}
\hline Socio-Demographic profile & Frequency $(\mathrm{N}=50)$ & Percentage \\
\hline \multicolumn{3}{|l|}{ Age } \\
\hline 21-29 years old & 20 & $40 \%$ \\
\hline 30-39 years old & 12 & $24 \%$ \\
\hline 40-49 years old & 9 & $18 \%$ \\
\hline 50-59 years old & 7 & $14 \%$ \\
\hline 60- years above old & 2 & $4 \%$ \\
\hline \multicolumn{3}{|l|}{ Mean: 31} \\
\hline \multicolumn{3}{|l|}{ SD: 5.2} \\
\hline \multicolumn{3}{|l|}{ Sex } \\
\hline Male & 21 & $42 \%$ \\
\hline Female & 29 & $58 \%$ \\
\hline \multicolumn{3}{|l|}{ Bachelors' Degree } \\
\hline BSEd MAPEH & 22 & $44 \%$ \\
\hline BSEd Other Major & 23 & $46 \%$ \\
\hline Other Program & 5 & $10 \%$ \\
\hline \multicolumn{3}{|l|}{ Highest Educational Attainment } \\
\hline Bachelors' Degree & 13 & $26 \%$ \\
\hline Masters' Units & 32 & $64 \%$ \\
\hline Masters' Degree & 5 & $10 \%$ \\
\hline Doctorate Units & 0 & $0 \%$ \\
\hline Doctorate Degree & 0 & $0 \%$ \\
\hline \multicolumn{3}{|l|}{ Number of Years in Teaching } \\
\hline $1-10$ years & 34 & $68 \%$ \\
\hline $11-20$ years & 8 & $16 \%$ \\
\hline $21-30$ years & 5 & $10 \%$ \\
\hline above years & 3 & $6 . \%$ \\
\hline
\end{tabular}

\section{Musicianship of the teacher respondents}

Table 2 presents the musicianship of the respondents. It can be noticed that tteachers obtained an overall mean of 2.41 interpreted as having low level of musicianship. Also, the overall standard deviation was 0.25 indicating narrow distribution of responses.

Musical Knowledge. MK of the respondent has an overall mean of 2.36 which indicated that respondents were found to have low level of proficiency in these areas. The overall standard deviation of 0.24 revealed that respondents answer was narrowly dispersed. It can be implied that respondents have insufficient knowledge in teaching general music class. 


\section{IRJE | Indonesian Research Journal in Education | | Vol. 5 | No. 1|June | Year 2021|}

Musical Skills. Looking at the respondent's musicianship in terms of musical skills, it can be seen that respondents were also found to have low level of musical skills based on the overall mean obtained. Results implied that respondents have insufficient musical skills in handling and teaching general music class.

Table 2. Summary of respondents' musicianship

\begin{tabular}{llll}
\hline Musicianship & Mean & SD & Descriptive Rating \\
\hline Musical Knowledge & 2.36 & 0.27 & Low \\
Musical Skills & 2.47 & 0.24 & Low \\
Overall Mean & 2.41 & 0.25 & Low \\
\hline
\end{tabular}

Legend:

3.26-4.00 Very High 2.51-3.25 High 1.76-2.50 Low 1.00-1.75 Very Low

\section{Relationship between socio-demographic profile and musicianship, pedagogical competencies and classroom anxieties of the respondents}

Table 3 illustrates the relationship between socio-demographic profile of the respondents and their musicianship, pedagogical competencies and classroom anxieties in teaching general music class.

Table 3. Relationship between respondents' socio-demographic profile and musicianship, pedagogical competencies and classroom anxieties

\begin{tabular}{|c|c|c|c|c|c|c|c|c|c|}
\hline \multirow{2}{*}{ Parameters } & \multicolumn{2}{|c|}{ Musicianship } & \multicolumn{4}{|c|}{ Pedagogical Competencies } & \multicolumn{3}{|c|}{ Classroom Anxieties } \\
\hline & $\overline{M K}$ & MS & $\mathrm{PP}$ & $\mathrm{CE}$ & INS & PR & $\mathrm{BC}$ & $\mathrm{PC}$ & $\mathrm{EC}$ \\
\hline Age & 1.88 & 1.29 & 1.74 & .025 & .070 & .152 & -.052 & -.047 & -.131 \\
\hline Sex & -.237 & -.197 & $-359 *$ & $-.369 * *$ & $\begin{array}{l}-.363^{*} \\
*\end{array}$ & -.171 & .278 & .207 & .154 \\
\hline Bachelors' degree & $-.518^{* *}$ & $\begin{array}{l}-.416 \\
* *\end{array}$ & $-.417^{* *}$ & $-.495^{* *}$ & $-.361 *$ & -.185 & $.655^{* *}$ & $.649 * *$ & $\begin{array}{l}.635 \\
* *\end{array}$ \\
\hline $\begin{array}{l}\text { Highest } \\
\text { educational } \\
\text { attainment }\end{array}$ & -.019 & .105 & .098 & .026 & 0.10 & .129 & .056 & -.003 & .004 \\
\hline Years in teaching & .277 & $.281 *$ & .256 & .043 & .194 & .279 & -.080 & -.129 & -.131 \\
\hline
\end{tabular}

\section{Relationship between socio-demographic profile and musicianship}

Bachelor's degree and musical knowledge and musical skills, it can be seen in table 3 that bachelor's degree has a negative significant relationship with musical knowledge and musical skills at 0.01 level of significance. Findings on the relationship of bachelor's degree and 


\section{IRJE | Indonesian Research Journal in Education | | Vol. 5 | No. 1|June | Year 2021|}

musical skills and knowledge suggest imperative connection of the variables. Because of its negative relationship, this might simply mean that a bachelor's degree with concentration on four components (i.e. MAPEH - as to Music, Arts, Physical Education and Health) compared to bachelor's degree with area of concentration in music education would have contrasting output in terms of acquired level of musical skills and knowledge. The former would have a lesser degree of musical knowledge and skills since developing aptitude in music is not that intense while the latter purely concentrates in enhancing one's skills and knowledge in music. Thus, it would offer sufficient proficiency in both areas. These findings likewise coincide with Danielson (2009)and Neilsen (1990) on assessing teacher competency. Teachers possessing degree with area of concentration purely in developing skills have the capability to be more effective educator compared to non-pure degree.

Years in teaching and musical skills, years in teaching also posted a moderate negative significant relationship to musical knowledge at 0.05 level of significance since the value in the significance is less than 0.05. The result might imply that the longer a person establishes himself or herself as music teacher will most likely develop sufficient musical knowledge. As proven in various music researches, Atabug (1996) gave emphasis on the importance of long period of preparation for a person to fully equip with musical skills and knowledge.

\section{Relationship between socio-demographic profile and pedagogical competencies}

Sex and planning and preparation, classroom environment and instruction, it has been revealed that sex have a moderate negative relationship to respondents' pedagogical competence in terms of planning and preparation, classroom environment and instruction. Findings likely imply that both male and female MAPEH teachers have equal capabilities to teach general music. However, results might also suggest that there are certain uniquely male and female issues in teaching general music. Harmonized with Tiger (2017), gender role suggests some degree of pedagogical competencies that make both male and female different in their teaching styles. Female music teachers tend to focus more on vocal music concerns while male music teachers most likely prefer instrumental music.

Bachelors' degree and planning and preparation, classroom environment and instruction, results disclosed that bachelor's degree established a negative significant relationship with planning and preparation and classroom environment and with instruction. Results likely offer evidences on the significant importance of what specific degree a person possesses to come up with certain pedagogical competency. Teachers with music degree perform higher level of pedagogical competencies in teaching general music compared to teachers not having pure music education degree. Compared with Atabug (1996), this norm has been consistent up to this present time. This has also been confirmed by Nielson (1990)and Danielson (2009) on evaluating teacher competency.

\section{Relationship between socio-demographic profile and teaching anxiety}

Bachelor's degree and behavioural, psychological and emotional characteristics of teaching anxiety, findings revealed that bachelors' degree posted a significant relationship with behavioural, 


\section{IRJE | Indonesian Research Journal in Education | | Vol. 5 | No. 1|June | Year 2021|}

psychological and emotional characteristics. These findings on the relationship of bachelor's degree and teaching anxiety in terms of behavioral, psychological, and emotional characteristics would have the tendency to negatively impact teachers teaching performance. Because of its high positive correlations, these might simply mean that, based on respondents' profiles on their undergraduate degree, teachers with bachelor's degree with little concentration in music components most likely experience high level of teaching anxiety. On the other hand, teachers with bachelor's degree having concentrated purely in music education most likely manifest lesser degree of teaching anxiety. These findings concur with previous researches on the acquired competency level of teachers through their area of concentration and how these would affect their pedagogical competencies (Macleod \& Nápoles, 2014; Johnson \& Matthews, 2015; Juchniewicz, 2010; Hamann et al., 1998). Specifically, the findings harmonize with De Vries (2013) who emphasized that generalist teachers tend to experience various degrees of teaching anxieties depending on their acquired level of skills and knowledge obtained during their formative years of experience. Koran and Koran (1981) also noted that music teachers might be at great risk to suffer from anxiety compared to other discipline since it requires sufficient musical skills.

\section{Relationship between musicianship and pedagogical competencies and teaching anxiety}

Table 4 presents the relationship between musicianship in terms of musical knowledge and musical skills and their pedagogical competencies as to planning and preparation, classroom environment, instruction, professional responsibilities and teaching anxieties such as behavioral, psychological and emotional characteristics.

Musical knowledge/musical skills and planning and preparation, musical knowledge and Preparation and Planning posted a very high positive relationship. Because musical knowledge is imperative to music analysis, the result most likely propose that planning and preparing for specific music class requires sufficient information and familiarity to specific music concept being taught. Likewise, a highly positive correlation has been revealed between musical knowledge and planning and preparation for general music class. This relationship most likely suggests that musical skills such as reading notations and playing a specific instrument are imperative to formulating objectives for the specific musical concept to be discussed. Thus, the necessity of possessing certain level of musical knowledge and skills most probably enhances teachers' ability to plan and organize meaningful music learning experience. Concurred with Guskey (1986), high performing schools with competent teaching task force require individual teachers to sustain and even enhance more their musical skills, knowledge, and attitudes essential to plan and prepare certain teaching tasks. Tschannen et al. (2007) agreed with the former in that teacher's belief of possessing high level of skills have the ability to plan and execute courses of action necessary to successfully achieve a specific teaching objective in a particular context.

Musical knowledge/musical skills and classroom environment, a strong positive relationship has similarly revealed between musical knowledge and classroom environment, Because of the necessity of adequate music knowledge and fluency on various music activities, the result most likely suggests that teachers having ample musical knowledge can manage classroom 


\section{IRJE | Indonesian Research Journal in Education | | Vol. 5 | No. 1|June | Year 2021|}

transitions properly. Also, a strong positive correlation has been noted between musical skills and classroom environment. The result tends to suggest that possessing high level of musicianship (e.g. note reading, teaching student how to play an instrument, or handling performing group) could create a friendly learning environment for students. This finding is consistent with Reeves (2002) stating teachers having high innate skills will likely manifest propensity to monitor and enhance student progress by providing them meaningful classroom environment of learning.

Musical knowledge/musical skills and instruction, musical knowledge has been likewise noted to have high positive correlation with instruction. The result most likely implies that the quality of classroom music instruction is dependent of the musical knowledge the teacher has acquired. Thus, this would dictate on teacher's flexibility in terms of teaching strategies for better music class dynamics. Strong positive correlation has also been noted with Instruction. The finding most likely implies that instruction in music classes would be the heart of the teaching and learning process. This is where teachers manipulate their teaching strategies and styles in utilizing instructional materials and implement music activities that would best describe and define specific music concept being learned by students. This result coincides with Reeves (2010) who looked at the positive learning environment by means of quality instruction. Their research studies revealed that by incorporating high quality instructional strategies, teachers tend to engage students into specific collaborative teamwork and decision-making.

Musical knowledge/musical skills and professional responsibilities, a positive significant relationship has been established between musical knowledge and professional responsibilities. This finding might possibly entail that having adequate musical knowledge can offer certain degree of confidence to involving oneself in the teaching and learning process professionally. Corresponds with the findings of Juchniewicz (2010) whose study examined the influence of professional responsibilities on teaching, it was found out that the higher the level of knowledge, teachers tend to manifest effective communication skills with students that would define teachers' professionalism.

Musical skills and professional responsibilities were likewise found to have a strong positive relationship. This result tends to imply that teachers would be confident enough to handle music classes and would exercise professionalism in their teaching as well as in dealing with other duties associated with professional work attitudes. This result confirms the findings of Napoles and MacLeod (2014) on teacher skills in observing professionalism inside the classroom and student engagement. They indicated that classroom discussions with teachers' high skills in observing professionalism most likely manifests high student engagement. 


\section{IRJE | Indonesian Research Journal in Education | | Vol. 5 | No. 1|June | Year 2021|}

Table 4. Relationship between respondents' musicianship, pedagogical competencies and classroom anxieties

\begin{tabular}{lrrrrrrrr}
\hline \multirow{2}{*}{ Musicianship } & \multicolumn{3}{c}{ Pedagogical Competencies } & \multicolumn{3}{c}{ Classroom Anxieties } \\
\cline { 2 - 8 } & PP & CE & INS & PR & BC & PC & EC \\
Musical Knowledge & $.730^{* *}$ & $.508^{* *}$ & $.646^{* *}$ & $.588^{* *}$ & & $-.521^{* *}$ & $-.573^{* *}$ & $-.516^{* *}$ \\
Musical Skills & $729^{* *}$ & $.546^{* *}$ & $.528^{* *}$ & $.485^{* *}$ & $-.480^{* *}$ & $-.502^{* *}$ & $-.413^{* *}$ \\
\hline
\end{tabular}

*. Correlation is significant at the 0.05 level (2-tailed)

**. Correlation is significant at the 0.01 level (2-tailed).

\section{Relationship between musicianship and teaching anxiety}

Musical knowledge/musical skills and behavioral characteristics, findings disclosed that musical knowledge established a high negative relationship with behavioral characteristics of teaching anxiety. The result implies that lesser musical knowledge tends to increase anxiousness in incorporating music related activities in the classroom in which teachers are unfamiliar with. Likewise, a strong negative correlation has been noted with musical skills and behavioral characteristics on teaching anxiety. The finding tends to suggest that teachers having insufficient musical skills be likely to feel bothered and worried in teaching musical concepts which are not familiar with them. Concur with the study of Gardner and Leak (1994) that teachers with inadequate skills had experienced teaching anxiety associated with the teaching process. Furthermore, Bernstein (2017) notes that teaching anxiety could lead to the development of unsuitable and ineffective teaching behaviors which is not ideal for education.

Musical knowledge/ musical skills and psychological characteristics, a high negative relationship has been likewise revealed between musical knowledge and psychological characteristics of teaching anxiety. The outcome specifically implies that teachers lacking the minimum requirement of musical knowledge to teach general music class have the propensity to constantly recall and review specific musical concepts to be taught. Furthermore, this psychological behavior tends to increase teachers inability to focus on certain teaching situation. Match with Atabug (1996) on the magnitude of skills acquired by a person will most likely experience lesser degree of focus problem but productive in various teaching contexts. Strong negative relationship has also been established between musical skills and psychological characteristics of teaching anxiety. The result revealed that teachers with inadequate musical skills tend to experience an increased concentration problem when teaching specific musical concept to students. This results to communication apprehension in the teaching and learning process. Similar to the finding of Roach (as cited in Wagner, 2011) which indicates a negative correlation between communication apprehension and the possibility of acquiring more or less teaching skills. Roach concludes teachers equipped with expertise most likely experience lesser psychological difficulty in teaching. 


\section{IRJE | Indonesian Research Journal in Education | | Vol. 5 | No. 1|June | Year 2021|}

Musical knowledge/musical skills and emotional characteristics, there had been a strong negative relationship linking musical knowledge and emotional characteristics of teaching anxiety). The impact of inadequate skills on musical facts or information tend to amplify teachers' apprehension or trepidation on executing and even integrating music activities to the teaching and learning process. The findings of Oral (2012), Houlihan et al. (1969), and Ammen, et al. (2002) on the impact and severity of emotional teaching anxiety have similar implications. Oral (2012) notes that majority of teachers tends to feel continuous uneasiness and discomfort when engaged in unfamiliar teaching task. Likewise, Houlihan et al. (1969) put emphasis on teachers with extreme level of teaching anxiety associated with controlling moods have the high tendency of not to employ cognitive restructuring strategies in the classroom. Furthermore, a high negative relationship was also found between musical skills and emotional characteristics of teaching anxiety. Based on the finding, teachers with inadequate musical skills have the tendency to decline teaching general music class and vulnerable to distress when teaching a musical concept is unsuccessful. This means that the lesser the degree of musical skills, the higher the level emotional anxiety. Coincide with Bernstein (2017), a person who struggles with anxious thoughts and emotional disturbance might have problems communicating concepts, answering student questions, or even give adequate response to students. In this manner, the impact of teaching anxiety might have negative effect on the nature of music discussion.

\section{Conclusion and Recommendations}

Based on the results of this study, the following conclusions were drawn. Socio-demographic profile of respondents was remarkably diverse. The largest number of participants belonged to age bracket of 20-29 years old and considered the youngest of all respondents. Dominated by female teachers, their educational attainments varied from bachelor's to master's degree. Some of whom disclosed of having master's degrees and units while none of them entered thus far in the doctorate degree program. Years of service from 1-10 years comprised the majority of respondents and only three revealed having more than 31 years in their teaching professions.

Teachers musicianship such as musical knowledge and skills were found to be low. With regards to their pedagogical competencies in terms of planning and preparation, classroom environment, instruction and professional responsibilities their perceived proficiency were found to be low. Subsequently, MAPEH teachers' most likely manifest inadequately capabilities or unskillful on these areas. On the other hand, Classroom environment and professional responsibilities revealed to be teachers' high level of pedagogical competencies. Consequently, teachers were most skillful on areas of classroom environment and in carrying out professional responsibilities. In terms of the overall characteristics of MAPEH teachers' teaching anxiety, the three areas (i.e., behavioral, psychological, and emotional) were perceived to have high level of teaching anxieties.

Musicianship (musical skills and musical knowledge) and pedagogical competencies were found to have very strong positive correlations. Thus, MAPEH teachers having insufficient musical skills and musical knowledge were most likely having less pedagogical competencies on planning/preparation and instruction in general music class. Furthermore, 


\section{IRJE | Indonesian Research Journal in Education | | Vol. 5 | No. 1|June | Year 2021|}

musicianship had been revealed to have high significant negative relationship with teaching anxiety. MAPEH teachers possessing inadequate musical skills and knowledge most likely have the tendency to constantly experience extreme behavioral, psychological, and emotional teaching anxieties. Based on the outcome of the study, it can be inferred that the higher the acquired musical skills and musical knowledge, the higher the level of teachers' pedagogical competencies. The lower the musical skills and musical knowledge, the higher the level of teaching anxiety in general music class. Since majority of the MAPEH teachers handling general music classes belonged to younger generation of teachers, they should be encouraged to take advance studies in music education for them to nurture their musical skills and knowledge on the pedagogical aspects of music education. This would enhance teachers' abilities to execute the minimum teaching and learning competencies in music education.

\section{Disclosure statement}

No potential conflict of interest or any other similar divergence associated with this research article by the author.

\section{Acknowledgments}

We would like to acknowledge the Indonesian Research Journal in Education for serving as a flat form for providing the researcher opportunity to internationally publish academic and scholarly works.

\section{References}

Ameen, E., Guffey, D., \& Jackson, C. (2002). Evidence of teaching anxiety among accounting educators . Journal of Education for Business, 1, 16-22.

Atabug, A. C. (1996). Readings in music education. Adamson University Collection.

Bernard, H. R. (2006). Research in anthropology. In Atltamira Press (Fourth Edi).

Bernstein, D. A. (2017). Dealing with teaching anxiety. Pratiques Psychologiques, 23(3), 233-241. https://doi.org/10.1016/j.prps.2017.04.003

Danielsons, C. (2009). Framework for teaching. The Danielson Group.

Devries, P. (2013). Generalist teachers' self-efficacy in primary school music teaching. Music Education Research, 15(4), 375-391.

Education, D. of. (2002). Do 25, s. 2002 -Implementation of the 2002 basic education curriculum.

Emiliasari, R. N. (2018). An analysis of teachers' pedagogical competence in lesson study of mgmp smp majalengka. Eltin Journal, 6(14), 22-33.

Funmilayo, A. (2019). Achievement: Frameworks for assessing music teaching, 1-21.

Gardner, L. E., \& Leak, G. K. (1994). The characteristics and correlates of teaching anxiety among college psychology teachers. Teaching of Psychology, 2132(1), 28-.

Hamann, D., Lineburgh, N., \& Paul, S. (1998). Teaching effectiveness and social skill development. Journal of Research in Music Education, 46(1), 87-101.

Harris, D. N., \& Sass, T. R. (2011). Teacher training, teacher quality and student achievement. Journal of Public Economics, 95(7-8), 798-812. 


\section{IRJE | Indonesian Research Journal in Education | | Vol. 5 | No. 1|June | Year 2021|}

Houlihan, M., Fraser, I., Fenwick, K., Fish, T., \& Moeller, C. (1969). Personality effects on teaching anxiety and teaching strategies in university professors. Canadian Journal of Higher Education, 39(1). https://doi.org/10.47678/cjhe.v39i1.494

Johansson, S. (2019). Teacher specialization and student perceived instructional quality : what are the relationships to student reading achievement? Content courtesy of Springer Nature, terms of use apply. Rights reserved. Content courtesy of Springer Nature, terms of us. 177-200.

Johnson, D., \& Matthews, W. (2015). Experienced general music teachers' instructional decision making. International Journal of Music Education, 35(2), 189-201.

Juchniewicz, J. (2010). The influence of social intelligence on effective music teaching. Journal of Research in Music Education, 58(3), 276-293.

Koran, J. J., \& Koran, M. Lou. (1981). The effects of teacher anxiety and modeling on the acquisition of a science teaching skill and concomitant student performance. Journal of Research in Science Teacbing, 18(4), 361-370.

Kovalev, D. A., Khussainova, G. A., \& Svetlana, T. (2016). Formation of various competencies in the process of training the future music teachers at the present stage. The International Journal of Environmental \& Science Education, 11(11), 4175-4183.

Macleod, B. R. B., \& Nápoles, J. (2014). The influences of teacher delivery and student progress on experienced teachers' perceptions of teaching effectiveness. Journal of Music Teacher Education, 24(3), 24-36.

Madsen, K., \& Cassidy, J. (2005). The effect of focus of attention and teaching experience on perceptions of teaching effectiveness and student learning. Journal of Research in Music Education, 53(3), 222-233.

Maranzano, C. (2002). Evaluating music teachers in Virginia : Practices and perceptions. https://doi.org/10.25774/w4-mw3a-5b71

Marcheva, P. (2018). The nature of the pedagogical skills of future music teachers in intercultural the nature of the pedagogical skills of future music teachers in intercultural education. Acta Paedagogica Vilnensia, 370, 71-80.

Mardapi, D., \& Herawan, T. (2018). Assessing teacher competence and its follow-up to support professional development sustainability, 20(1), 106-123.

Mohanna, K., Chambers, R., \& Wall, D. (2007). Developing your teaching style: Increasing effectiveness in healthcare teaching, Postgrad Med J., 83(977), 145-7

Moreno-Murcia, J. A., Silveira Torregrosa, Y., \& Belando Pedreño, N. (2015). Questionnaire evaluating teaching competencies in the university environment. Evaluation of teaching competencies in the university. Journal of New Approaches in Educational Research, 4(1), 54-61.

Nielsen, L. (2014). Teacher evaluation: Archiving teaching effectiveness. Music Education Journals, 101(1), 63-69.

Oral, B. (2012). Student teachers' classroom management anxiety: A study on behavior management and teaching management. Journal of Applied Social Psychology, 42(12), 2901-2916.

Peker, M. (2009). Pre-service teachers' teaching anxiety about mathematics and their learning styles. Eurasia Journal of Mathematics, Science and Technology Education, 5(4), 335-345.

Plaut, E. A. (1998). Psychotherapy of performance anxiety. Medical Problems of Performing Artists, 3, 113-118. 


\section{IRJE | Indonesian Research Journal in Education | | Vol. 5 | No. 1|June | Year 2021|}

Reeves, D B. (2010). Transforming professional development into student results. Alexandria, VA: Association for Supervision and Curriculum Development. ASCD.

Reeves, D. B. (2002). Making standards work: How to implement standards-based assessments in the classroom, school, and district. Advance Learning Press.

Richardson, P. W., \& Watt†, H. M. G. (2006). Who chooses teaching and why? Profiling characteristics and motivations across three australian universities. Asia-Pacific Journal of Teacher Education, 34(1), 27-56.

Roach, D. k. (2003). Teaching assistant anxiety and coping strategies in the classroom, Communication Research Reports, 20(1), 81-89.

Sinclair, K. E., \& Ryan, G. (1987). Teacher anxiety, teacher effectiveness, and student anxiety. Elsviere, LTD, 3(3), 249-253.

Spielberger, C. D. (1989). State-trait anxiety inventory: Bibliography (2nd ed.). Consulting Psychologists Press.

Sumual, M., \& Ali, M. (2017). Evaluation of Primary school teachers' pedagogical competence in implementing the curriculum. Journal of Education and Learning,11(3), 343-350.

Taebel, D. K. (1990). An assessment of the classroom performance of music teachers. Journal of Research in Music Education, 38(1), 5-23.

Thomas, J. C., \& Thoresen, C. E. (1976). Teacher anxiety: A review with recommendation. Review of Educational Research, 6(2), 159-180.

Thomas, R. (1976). Teacher Anxiety: A review with recommendations. Review of Educational Research, 46(2), 159-184.

Tiger, Ro. (2017). Male elementary general music teachers: A Phenomenological study. Journal of Music Teacher Education, 26(2), 5-13.

Tschannen-moran, M., \& Woolfolk, A. (2007). The differential antecedents of self-efficacy beliefs of novice and experienced teachers. Teaching and Teacher Education, 23, 944 956.

\section{Biographical notes}

RAYVIN D. PESTAÑO is an assistant professor at College of Education, Central Luzon State University. A doctor of philosophy in development education graduate at CLSU's Department of Education and Related Studies. His research interest focuses on music, physical education, sports, teaching and learning and school management, e-mail: rayvin.pestano@clsu2.edu.ph

FLORANTE P. IBARRA is an accredited full-fledged professor at Central Luzon State University Graduate School of Education in the Philippines. He teaches courses such as advance methods of educational research, philosophy of education, and philosophy in educational management ethics. A multi-awarded music educator and music researcher, his interests focus on classroom instructions, school management system, teaching and learning musical traditions and cultural anthropology. He published various research articles in reputable international journals under Social Science Citation Indexed, Emerging Sources Citation Indexed and Scopus, e-mail: fpibarra@clsu.edu.ph 